\title{
Diet of Lontra longicaudis (Olfers, 1818) (Carnivora: Mustelidae) in Three Limnic Systems in Southern Rio Grande do Sul State, Brazil
}

\author{
Fernando Marques Quintela ${ }^{1 *}$, Luiz Guilherme Schultz Artioli ${ }^{1}$ and Rafael Almeida \\ Porciuncula $^{2}$ \\ ${ }^{1}$ Universidade Federal do Rio Grande do Sul; Av. Bento Gonçalves, 9500; 91501-970; Porto Alegre - RS - Brasil. \\ ${ }^{2}$ Universidade Federal do Rio Grande; Av. Itália s/n; 96201-900; Rio Grande - RS - Brasil
}

\begin{abstract}
The aim of the present work was to study the diet of Lontra longicaudis in three limnic systems (anthropogenic shallow lakes, pluvial channel and coastal stream) in Rio Grande do Sul State coastal plain, southern Brazil. Fishes were the most consumed item in all the three systems, being Mugilidae the most representative family in the pluvial channel and coastal stream and Cichlidae in the shallow lakes. Other identified items were mollusks, insects, crustaceans, amphibians, reptiles, birds and mammals and vegetal fragments. The high frequency of birds in the shallow lakes was remarkable, considering the lower frequencies of this item in previous investigations on the species diet. There was a high frequency of swamp eels (Synbranchidae, Synbranchus marmoratus) in the pluvial channel and shallow lakes, which were usually absent or found in low frequencies in previous studies.
\end{abstract}

Key words: anthropogenic shallow lakes, pluvial channel, coastal stream, neotropical otter

\section{INTRODUCTION}

The sub-family Lutrine comprises 13 otter species, distributed in all the continents, except Australia and Antarctica (Wozencraft 2005). South America host four species and the Neotropical river otter Lontra longicaudis (Olfers 1818) is the widest distributed, ranging from Mexico to northern Argentina (Mason, 1990; Eisenberg and Redford 1999). Studies on the feeding habits of the neotropical river otter have been conducted in several environments in Costa Rica (Spinola and Vaughan 1995; 1998), Ecuador (Uteras et al. 1998), northern Argentina (Parera 1993; Gori et al. 2003), southern and southeastern Brazil (Passamani and Camargo 1995; Helder-José and De Andrade 1997; Pardini 1998; Colares and
Waldemarin 2000; Quadros and Monteiro-Filho 2001; Alarcon and Simões-Lopes 2004; Kasper et al. 2004; 2008; Quintela et al. 2008). These studies revealed fishes as a major prey item, while other items such as crustaceans, insects, mollusks, mammals, birds, amphibians and vegetables were also recorded in varied frequencies.

Although there is relative knowledge on $L$. longicaudis feeding ecology, there are few studies evaluating the diet composition of the species in the areas characterized by the presence of distinct limnic systems. These studies provide data on the species diet spectrum, considering that the environments with different physiognomies host different types of potential preys (Ricklefs 2003). The coastal plain of Rio Grande do Sul State, southern Brazil is hydrologically characterized by the existence of shallow freshwater ecosystems

*Author for correspondence: fmquintela@yahoo.com.br 
such as streams, lagoons and wetlands (Vieira and Rangel, 1988; Albertoni et al. 2007). In addition to these natural water bodies, artificial systems represented by the drainage channels and anthropogenic shallow lakes are also present in the region. Channels built for the drainage and pluvial water flow are common in the coastal cities of Rio Grande do Sul State (Albertoni and Palma-Silva 2006) while a set of anthropogenic shallow lakes are present in an urban area in the city of Rio Grande (Votto et al. 2006; Albertoni et al. 2007). The objective of the present work was to study the diet of $L$. longicaudis in three distinct limnic systems in southern Rio Grande do Sul State, aiming on an approximation about the diet spectrum of the species in this region.

\section{MATERIAL AND METHODS}

\section{Study area}

The study was conducted in the municipality of Rio Grande, located in the southern coastal plain of Rio Grande do Sul State, southern Brazil. The climate in the region is classified as $\mathrm{Cfa}$ of Köppen, with temperatures varying from $9.5^{\circ} \mathrm{C}$ in July (minimum average) to $27.2^{\circ} \mathrm{C}$ (maximum average). The monthly precipitation average is $104 \mathrm{~mm}$ and the rainiest months are July, August and September (Vieira 1983).

Scat samples were collected in three limnic systems: 1. "Navio Altair" coastal stream $\left(32^{\circ} 17^{\prime} \mathrm{S}, 52^{\circ} 16^{\prime} \mathrm{W}\right)$ (Fig. 1). A coastal stream originated in the marshes, crossing sandy dunes and sandy plains and discharging in the Atlantic Ocean. The extension of ca. $4.3 \mathrm{~km}$; meandering physiognomy; average width of $2 \mathrm{~m}$ and $20 \mathrm{~m}$ in the mouth; maximum measured depth $1.65 \mathrm{~m}$ (measured with a 50m tape measure in 10 sections of the stream). Vegetation was visually sampled in 10 sections of each system and nomenclature follows Cordazzo and Seeliger (1995). Vegetation on the edges is composed mainly by gramineous and herbaceous such as Andropogon arenarius, Spartina ciliata, Blutaparon portulacoides, Hydrocotyle ranunculoides, Triglochin striata, Scirpus olneyi, Typha dominguensis. The floating Spirodela sp. covers mainly the protected backwaters; sampling period: from August 2008 to January 2010; 2. Anthropogenic shallow lakes in Campus Carreiros of Universidade Federal do Rio

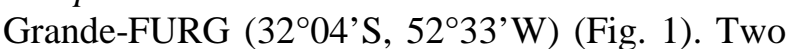

shallow palustrine water bodies formed by accumulation from pluvial precipitation in depressions originated by the removal of the sand, which was used in the construction of buildings in the campus; Lake A: area of ca. 1.5 ha, vegetal covering of edges composed mainly by herbaceous Alternanthera philoxeroides, Enydra sp., Juncus sp. and sparse arboreal Erythrina crista-galli and Salix humboldtiana; Lake B: area of ca. 1.2 ha, vegetal covering of edges composed mainly by herbaceous Typha dominguensis and Scirpus sp.; distance between lakes $300 \mathrm{~m}$; sampling period: from May 2007 to May 2008; 3. Pluvial channel in Permanent Protection Area $\mathrm{n}^{\circ} 6 \quad\left(32^{\circ} 07^{\prime} \mathrm{S}\right.$, $52^{\circ} 09^{\prime} \mathrm{W}$ ) (Fig. 1). An artificial drainage channel in the border of peat forests and marshes, ca. $1.6 \mathrm{~km}$ length and $10 \mathrm{~m}$ width; vegetation on the edges composed mainly by herbaceous Ranunculus apiifolius, Enydra sp. Hydrocotyle ranunculoides, Scirpus sp., Bromelia antiacantha, Saggitaria montevidensis, Eryngium pandanifolium and arboreal Erythrina crista-galli; the floatings Azolla filiculoides and Pistia stratiostes cover a significant trench of the channel during spring/summer; sampling period: from November 2007 to February 2010.

\section{Data sampling}

The diet composition of $L$. longicaudis was determined based on the identification of scat remains. All the scats found were collected, stored in individual labeled plastic bags and frozen. Afterwards, scats were washed through a $1 \mathrm{~mm}$ sieve and solid remains were dried in an oven at $36^{\circ} \mathrm{C}$. Screening was realized with the aid of a stereoscopic microscope. The consumed taxa were determined based on identification of remains such as scales, vertebrae, hair, carapaces and other structures which were compared with specimens stored in a reference collection of the study areas. The frequency of occurrence (FO) of each prey item was calculated by the rate of the number of scats containing such item over the total number of analyzed scats (Erlinge 1968).

The relative importance (RI) of each prey category (i) (mollusks, crustaceans, insects, fishes, amphibians, reptiles, birds, mammals) was verified for each system by the rate of FO of such prey category over the sum of the frequency of occurrence of all prey categories: RI = $\left(\mathrm{FO}_{\mathrm{i}} / \sum \mathrm{FO}\right) \mathrm{x} 100$. The RI values of each prey category were compared to the mean and the 
categories with values over the mean were considered frequent (Artioli et al. 2009).

The food niche breadth was calculated for each sampled system. Levins index (Krebs, 1999) was used as a measurement of food niche breadth for all food categories (mollusks, crustaceans, insects, fishes, amphibians, reptiles, birds, mammals), given as: $\mathrm{B}_{\mathrm{s}}=(\mathrm{B}-1) /(n-1)$, where $\mathrm{B}_{\mathrm{s}}$ is the standardized niche breath, $\mathrm{B}=1 / \sum p_{i}^{2}$, where $p$ is the frequency of each item in the total sample and $n$ is the total number of food categories. The values of $B_{s}$ vary from zero to one. A value close to one implies in a well distributed diet (items of the distinct categories consumed in equal proportions) while a value close to zero implies that items of few categories were consumed in high proportion and items of most categories were consumed in low proportion.

We evaluated diet similarity for each pair of systems by using Pianka's index, $O_{j k}=\sum p_{i j} p_{i k} /\left(\sum\right.$ $\left.p_{i j}^{2} \sum p_{i k}{ }^{2}\right)^{1 / 2}$, where $p i$ is the frequency of occurrence of prey item $i$ in the diet of systems $j$ and $k$ (Pianka, 1973). Pianka's index $(O)$ varies between 0 (total separation) and 1 (total overlap).
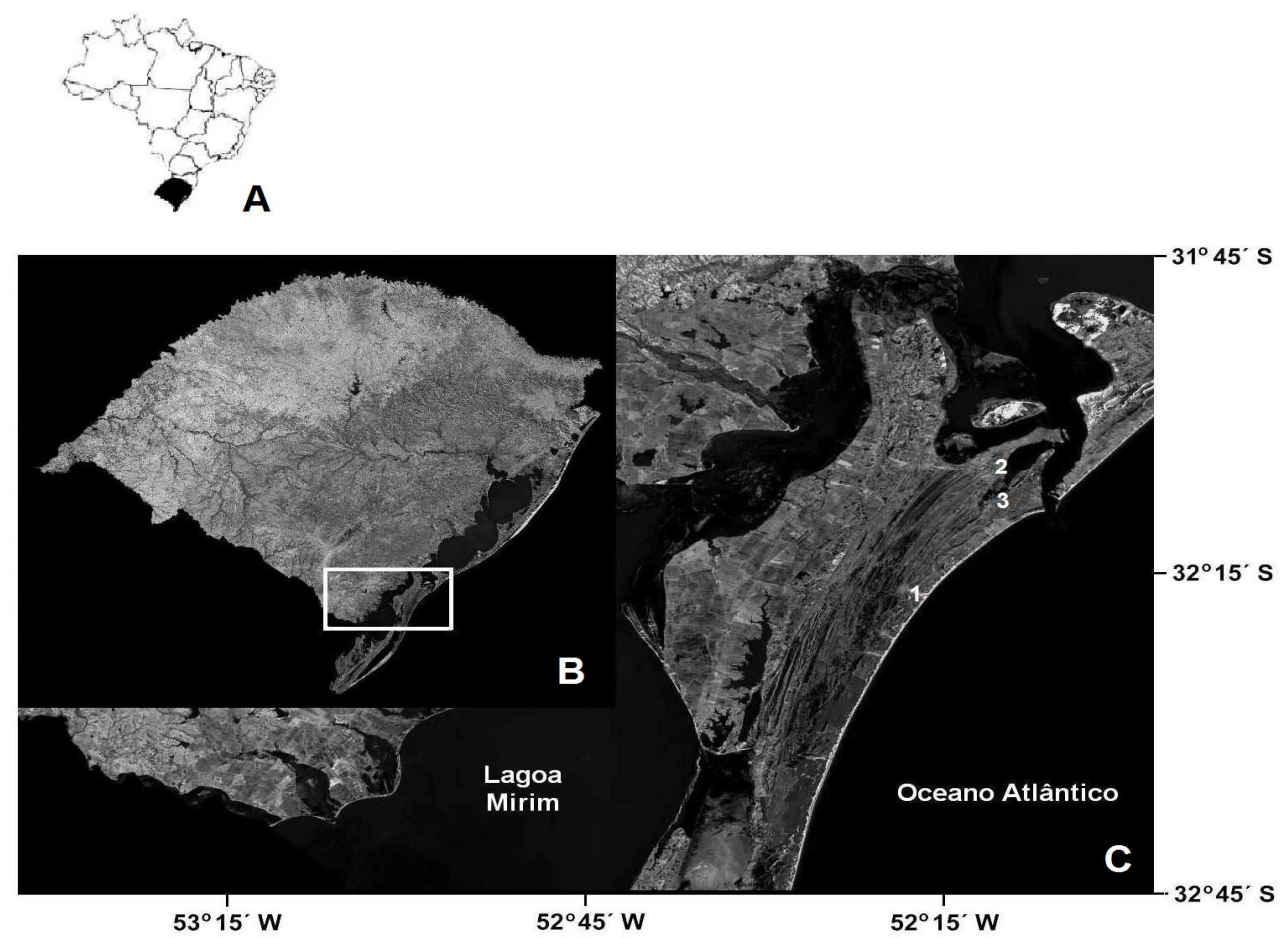

Figure 1 - Location of Rio Grande do Sul State (A), part of southern Coastal Plain (B) and studied limnic systems (C), being: 1) "Navio Altair" coastal stream, 2) anthropogenic shallow lakes at Universidade Federal do Rio Grande - FURG, 3) pluvial channel in Permanent Protection Area 6.

\section{RESULTS}

\section{"Navio Altair" coastal stream}

A total of 139 scats collected from August 2008 to January 2010. A total of 19 identified taxa. The identified food items and their frequency of occurrence were fish $(89.92 \%)$, decapods $(47.48 \%)$, gastropod $(10.79 \%)$, cricetid rodents $(8.63 \%)$, birds $(3.59 \%)$, amphibians $(2.87 \%)$, dipsadid snakes $(2.17 \%)$ and insects $(1.43 \%)$. Among fishes, the identified families were
Mugilidae (58.99\%), Cichlidae (56.83\%), Characidae (32.37\%), Callichthyidae (18.70\%), Synbranchidae (17.26\%), Erythrinidae and Curimatidae $(7.19 \%$ each) and Heptapteridae $(5.75 \%)$. Bone fragments of an unidentified siluriform occurred in one sample $(0.71 \%)$. Decapod crustaceans correspond to crabs $(47.48 \%)$ and shrimps $(0.71 \%)$ while insects comprise belostomatid heteropterans $(0.71 \%)$ and unidentified remains (0.71\%) (Tab.1, Fig. 2). 
Mollusks, crustaceans and fishes were found in all seasons. Amphibians were recorded in the autumn and spring while snakes were found in the summer, autumn and spring. Birds were recorded in the summer, autumn and winter while mammals were identified in the winter and spring. Hexapods were recorded only in the summer. Crustacean and fish were frequent prey categories (Tab.2).

Table 1 - Absolute frequency and frequency of occurrence (between parenthesis) of prey items found in Lontra longicaudis scats from three limnic systems in Rio Grande do Sul Coastal Plain.

\begin{tabular}{|c|c|c|c|}
\hline Food items & Coastal stream $(n=139)$ & Shallow lakes $(n=116)$ & Pluvial channel $(n=80)$ \\
\hline Vegetal (grass) & & & $3(3.75)$ \\
\hline \multicolumn{4}{|l|}{ Molusca } \\
\hline \multicolumn{4}{|l|}{ Gastropoda } \\
\hline \multicolumn{4}{|l|}{ Mesogastropoda } \\
\hline \multicolumn{4}{|l|}{ Pilidae } \\
\hline Pomacea sp. & $15(10.79)$ & $1(0.86)$ & $1(1.25)$ \\
\hline Planorbidae & & $14(12.06)$ & \\
\hline \multicolumn{4}{|l|}{ Arthropoda } \\
\hline \multicolumn{4}{|l|}{ Hexapoda } \\
\hline Coleoptera & & $9(7.75)$ & $1(1.25)$ \\
\hline \multicolumn{4}{|l|}{ Heteroptera } \\
\hline Belostomatidae & $1(0.71)$ & $3(2.58)$ & $3(3.75)$ \\
\hline not identified & $1(0.71)$ & $3(2.58)$ & $4(5.00)$ \\
\hline \multicolumn{4}{|l|}{ Crustacea } \\
\hline \multicolumn{4}{|l|}{ Decapoda } \\
\hline Brachyura & $66(47.48)$ & & $27(33.75)$ \\
\hline Dendrobranchiata & $1(0.71)$ & & \\
\hline Isopoda & & $4(3.44)$ & \\
\hline \multirow{2}{*}{\multicolumn{4}{|c|}{$\begin{array}{l}\text { Chordata } \\
\text { Actinopterygii }\end{array}$}} \\
\hline & & & \\
\hline \multicolumn{4}{|l|}{ Characiformes } \\
\hline \multicolumn{4}{|l|}{ Erythrinidae } \\
\hline Hoplias malabaricus & $10(7.19)$ & $31(26.72)$ & $5(6.25)$ \\
\hline Characidae & $45(32.37)$ & $3(2.58)$ & \\
\hline \multicolumn{4}{|l|}{ Curimatidae } \\
\hline Cyphocharax voga & $10(7.19)$ & $4(3.44)$ & $10(12.50)$ \\
\hline \multicolumn{4}{|l|}{ Siluriformes } \\
\hline Callichthyidae & $26(18.70)$ & $40(34.48)$ & $6(7.50)$ \\
\hline \multicolumn{4}{|l|}{ Heptapteridae } \\
\hline Rhamdia aff. quelen & $3(2.15)$ & $2(1.72)$ & \\
\hline Pimelodella australis & $5(3.59)$ & $1(0.86)$ & \\
\hline \multicolumn{4}{|l|}{ Perciformes } \\
\hline Cichlidae & $79(56.83)$ & $66(56.39)$ & $9(11.25)$ \\
\hline \multicolumn{4}{|l|}{ Mugilidae } \\
\hline Mugil liza & $82(58.99)$ & & $35(43.75)$ \\
\hline \multicolumn{4}{|l|}{ Synbranchiformes } \\
\hline \multicolumn{4}{|l|}{ Synbranchidae } \\
\hline Synbranchus marmoratus & $24(17.26)$ & $45(38.79)$ & $34(42.50)$ \\
\hline not identified & $1(0.71)$ & $4(3.44)$ & $1(1.25)$ \\
\hline \multicolumn{4}{|l|}{ Amphibia } \\
\hline Anura & $4(2.87)$ & $2(1.72)$ & $5(6.25)$ \\
\hline Reptilia & & & \\
\hline Squamata & & & \\
\hline Dipsadidae & & & \\
\hline Liophis semiaureus & $3(2.17)$ & $1(0.86)$ & $5(6.25)$ \\
\hline Helicops infrataeniatus & & $5(4.31)$ & $1(1.25)$ \\
\hline Aves & $5(3.59)$ & $49(42.24)$ & $5(6.25)$ \\
\hline Mammalia & & & \\
\hline Cingulata & & & \\
\hline Dasypodidae & & & $1(1.25)$ \\
\hline Rodentia & & & \\
\hline Myocastoridae & & & \\
\hline Myocastor coypus & & & $1(1.25)$ \\
\hline Cricetidae & $12(8.63)$ & $2(1.72)$ & $6(7.50)$ \\
\hline
\end{tabular}



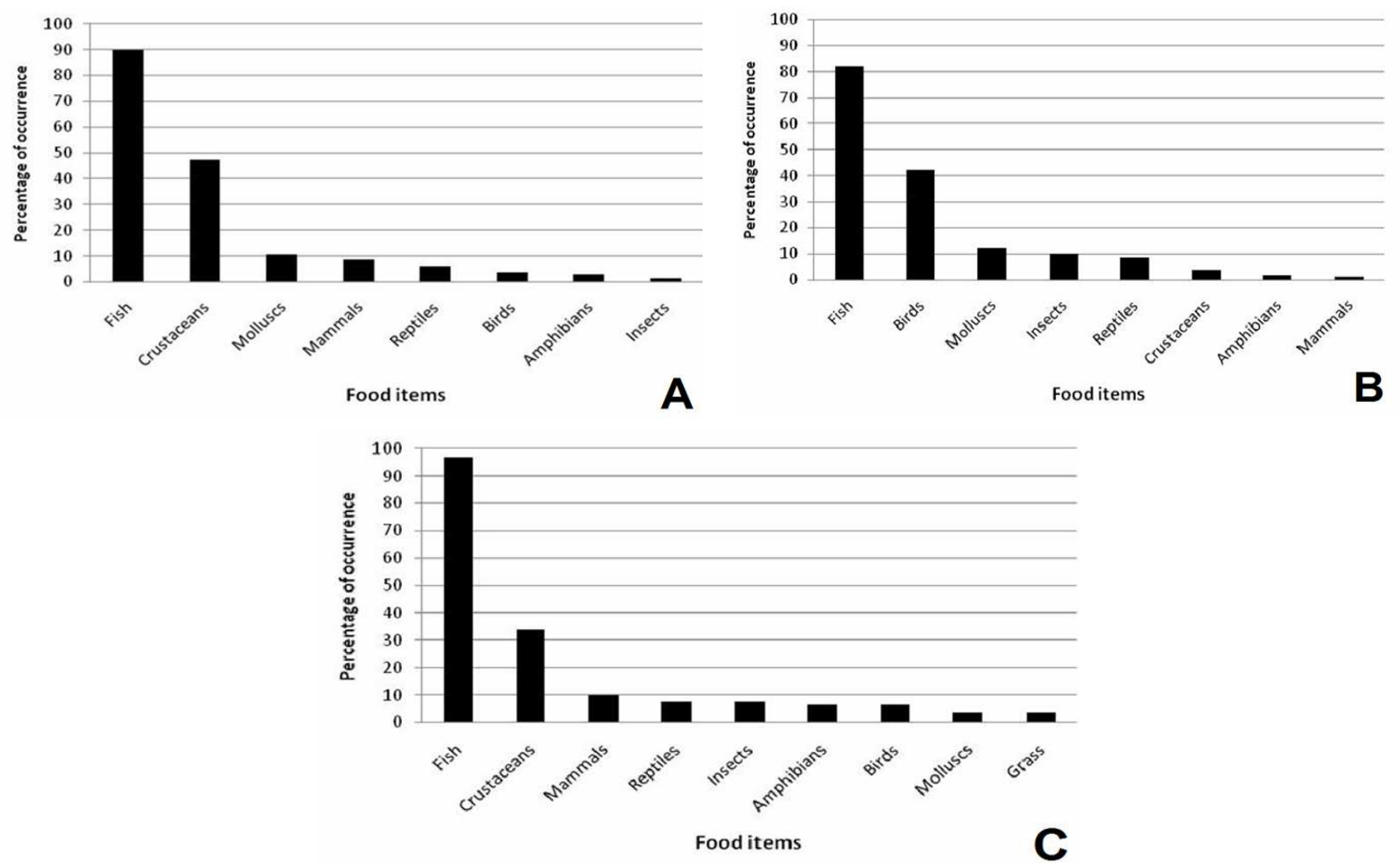

Figure 2 - Frequency of occurrence of food items identified in Lontra longicaudis scats from three limnic systems in Rio Grande do Sul State Coastal Plain. A) 1) "Navio Altair" coastal stream, B) anthropogenic shallow lakes at Universidade Federal do Rio Grande FURG, C) pluvial channel in Permanent Protection Area 6.

\section{Anthropogenic shallow lakes}

A total of 116 scats collected from May 2007 to May 2008. A total of 20 identified taxa. The identified food items and their frequency of occurrence were fish (81.89\%), birds $(42.24 \%)$, mollusks $(12.06 \%)$, insects $(10.34 \%)$, reptiles $(8.62 \%)$, isopod crustaceans $(3.44 \%)$, cricetid rodents and amphibians (1.72\% each). Among fishes, the identified families were Cichlidae (56.89\%), Synbranchidae (38.79\%), Callichthyidae (34.48\%), Erythrinidae (26.72\%), Curimatidae $(3.44 \%)$, Characidae and Heptapteridae $(2.58 \%$ each). Unidentified fish remains occurred in four samples (3.44\%). Identified reptiles comprise dipsadid snakes $(5.17 \%)$ and testudines $(4.31 \%)$. Insects were represented by coleopterans $(7.75 \%)$, belostomatid heteropterans and unidentified remains $(2.58 \%$ each) (Tab. 1, Fig. 2).

Mollusks, insects, fishes, birds and testudines were recorded in all seasons. Snakes were found in the summer, autumn and spring while amphibians were recorded only in the autumn. Isopod crustaceans were found in the winter and spring while mammals were recorded only in the autumn. Fish and bird were frequent prey categories (Tab.2).

\section{Pluvial channel}

A total of 80 scats collected from November 2007 to February 2010. A total of 19 identified taxa. The identified food items and their frequency of occurrence were fish (82.5\%), decapod (33.75\%), mammals (10\%), dipsadid snakes and insects (7.5\% each), amphibians and birds (6.25\% each), vegetal remains $(3.75 \%)$ and gastropod mollusks $(1.25 \%)$. Among fishes, the identified families were Mugilidade (43.75\%), Synbranchidae $(42.5 \%)$, Characidae (17.5\%), Curimatidae (12.5\%), Cichlidae (11.25\%), Callichthyidae (7.5\%) and Erythrinidae (6.25\%). Insects comprise belostomatid heteroptereans (3.75\%), coleoptereans $(1.25 \%)$ and unidentified remains $(3.75 \%)$. Mammals comprise cricetid rodents (7.5\%), coypu $(1.25 \%)$ and armadillo (1.25\%) (Tab. 1, Fig. 2).

Insects, crustaceans and fishes were found in all seasons. Amphibians, birds and mammals were 
recorded in the winter and spring. Mollusks were recorded only in the spring while grass and snakes were found only in the winter. Crustacean and fish were frequent prey categories (Tab.2).
Values of Levins niche breadth index and Pianka's diet similarity index are shown on Tables 3 and 4 respectively.

Table 2 - Values of relative importance of prey categories of Lontra longicaudis diet in three limnic systems in Rio Grande do Sul Coastal Plain. Frequent items are marked in bold.

\begin{tabular}{lccc}
\hline Prey categories & Coastal stream & Anthropogenic shallow lakes & Pluvial channel \\
\hline Mollusks & 6.28 & 7.43 & 2.17 \\
Insects & 0.82 & 6.38 & 4.28 \\
Crustaceans & $\mathbf{2 7 . 8 8}$ & 2.11 & $\mathbf{2 1 . 0 9}$ \\
Fish & $\mathbf{5 2 . 7 6}$ & $\mathbf{5 0 . 7 7}$ & $\mathbf{5 5 . 3 0}$ \\
Amphibians & 1.70 & 1.05 & 3.59 \\
Reptiles & 3.40 & 5.33 & 4.28 \\
Birds & 2.11 & $\mathbf{2 6 . 1 9}$ & 3.59 \\
Mammals & 5.05 & 0.74 & 5.70 \\
\hline
\end{tabular}

Table 3 - Values of Levins niche breadth $\left(\mathrm{B}_{\mathrm{s}}\right)$ of Lontra longicaudis diet in three limnic systems in Rio Grande do Sul Coastal Plain.

\begin{tabular}{ll}
\hline System & Bs \\
\hline Coastal stream & 0.23 \\
Anthropogenic shallow lakes & 0.28 \\
Pluvial channel & 0.30 \\
\hline
\end{tabular}

Table 4 - Values of Pianka's diet similarity index $(O)$ of Lontra longicaudis diet in three limnic systems in Rio Grande do Sul Coastal Plain.

\begin{tabular}{lc}
\hline Systems & $\boldsymbol{O}$ \\
\hline Coastal stream $v s$. Anthropogenic shallow lakes & 0.728 \\
Coastal stream $v s$. Pluvial channel & 0.803 \\
Anthropogenic shallow lakes $v s$. Pluvial channel & 0.814 \\
\hline
\end{tabular}

\section{DISCUSSION}

Lontra longicaudis presented a varied diet in the studied limnic systems, considering the occurrence of the diverse food items identified in the sampled scats. Fishes, however, represented the most consumed item, as observed in all of the previous studies on diet of $L$. longicaudis (e.g. Passamani and Camargo 1995; Spinola and Vaughan 1995; 1998; Helder-José and De Andrade 1997; Pardini 1998; Uteras et al. 1998; Colares and Waldemarin 2000; Quadros and Monteiro-Filho 2001; Gori et al. 2003; Alarcon and Simões-Lopes 2004; Kasper et al. 2004; 2008; Quintela et al. 2008) and on the diet of other species of Lutrinae such as Lutra maculicollis (Larivière 2002; Kruuk and Goudswaard 2008), Lutrogale perspicillata (Kruuk et al. 1994; Haque and Vijayan 1995), Lutra lutra (Lanski et al. 2007; Blanco-Garrido et al. 2008; Parry et al. 2011) and Lontra canadensis (Noordhuis 2002).
The high prevalence of fishes reflected in low values of niche breadth and in high similarity of the diet in the analyzed systems. It is also remarkable the similarity in the number of taxa found in the samples of each system. Despite of similarity in richness, differences in the taxa composition were observed, which may be caused by differences in physiognomic features of each system favoring the occurrence, abundance and availability of certain groups. Considering records of daily movements of up to $1 \mathrm{~km}$ (NakanoOliveira et al., 2004) should also be considered the utilization of distinct limnic systems located adjacent to or near the studied areas so that remains found in latrines in a given area may not necessarily indicate the presence of the corresponding taxa in this same area. Kasper et al. (2008) also found low values of niche breadth in Taquari Valley, which were similar to the values found in the present study. Colares and Waldemarin (2000) detected differences in prey 
composition in three areas of Rio Grande do Sul Coastal Plain.

Mugilidae and Cichlidae were the most predated fish family in the studied systems. Three species of cichlids (Australoheros facetus, Geophagus brasiliensis and Crenicichla lepidota) were collected in all of three systems while Mugil liza was commonly captured in random fish samples in the coastal stream and pluvial channels, adjacent channels and streams in these two areas. Cichlidae was also the most abundant family recorded by Helder-José and De Andrade (1997), Quadros and Monteiro-Filho (2001) and Quintela et al. (2008), being the two first studies conducted in a dam and rivers in Atlantic Forest, respectively, and the last in a Pampa's coastal stream. Despite its higher frequency among prey items, Quadros and Monteiro-Filho (2001) found a negative selection of the cichlid Geophagus brasiliensis, with a lower consumption when compared to its environmental availability. The highest frequency of cichlids in the scat samples from the anthropogenic shallow lakes and the coastal stream investigated in the present study could be a reflex of the high abundance of these fishes in these environments. Individuals of $G$. brasiliensis and C. lepidota were commonly captured in the two systems, but the lack of an appropriate standardized applied method of fish sampling does not allow any conclusion concerning fish abundance in these environments. Mugil liza is an abundant species in Patos Lagoon estuary and adjacent coastal zones (Fischer et al., 2004; as M. platanus). Its highest frequency in samples from "Navio Altair" coastal stream and the pluvial channel highlights the coastal-estuarine influence over these lymnic systems. It is also noteworthy the high frequency of the swamp eel Synbranchus marmoratus (Synbranchidae) in the pluvial channel and shallow lakes, a fish species usually not determined or found in low frequencies in the otter diet (see Quintela et al. 2008).

Identification on predated species/groups provides relevant information on predatory behavior and use of microhabitats. Mugil liza is active in midwater and surface (Tagliani 1994; Fischer et al., 2004). Cichlids are sedentary (Koch et al., 2000) and data on habitat occupancy of $G$. brasiliensis and A. facetus indicate the utilization of midwater and vegetated bottoms by the first (Tagliani 1994; Barreto and Aranha 2005) and vegetated bottoms and edges by the other (Barreto and Aranha 2005; Rosso 2006). Characids are active in midwater in backwaters, vegetated shallow zones and edges (Tagliani 1994; Rosso 2006). Hoplias malabaricus is active when juvenile, becoming more sedentary when adult (Bemvenuti and Moresco 2005; Rosso 2006), inhabiting midwater, vegetated edges and sandy bottoms (Casatti et al. 2001; Ferreira 2007). Cyphocharax voga is active in midwater (Tagliani 1994) and feeds on bottom organic matter when adult (Bemvenuti and Moresco 2005). Callichthyds and heptapterids have benthic habits (Tagliani 1994; Koch et al., 2000; Rosso 2006) while $S$. marmoratus was classified as necktobenthic (Ferreira 2007).

Decapod crustaceans were well representative in the pluvial channel and coastal stream samples. Decapods were also commonly found in several studies (e.g. Helder-José and De Andrade 1997; Pardini 1998; Colares and Waldemarin 2000; Quadros and Monteiro-Filho 2001; Alarcon and Simões-Lopes 2004; Quintela et al. 2008; Carvalho-Junior et al. 2010), whose authors attribute the high frequencies to the species low motility and availability in the environment. In random sampling performed in both pluvial channel and coastal stream, decapods (mainly Callinectes sapidus) were commonly trapped and may represent a highly available food resource in these systems. Crustaceans were the most common item found in the diet of Lontra provocax (Medina-Vogel and Gonzalez-Lagos 2008), Lontra felina (Medina-Vogel et al. 2004), Aonyx cinerea (Kruuk et al. 1994), A. capensis (Van der Zee 1981; Kruuk and Goudswaard 2008; Somers and Purves, 2008).

Isopod crustaceans, recorded in low frequency in the anthropogenic shallow lakes, had not yet been recorded in L. longicaudis diet before the present. Isopods were also recorded by Georgiev (2006) in the diet of Eurasian otter Lutra lutra in southeastern Bulgaria. This author considered that isopods and other small invertebrates found in the scats could represent stomach contents of other $L$. lutra prey, which may have also occurred for isopods and planorbid mollusks in anthropogenic shallow lakes. Other identified invertebrates (gastropod mollusks, insects) occurred in relative low frequencies, which is in agreement with most of the previous studies (e.g. Helder-José and De Andrade, 1997; Quadros and Monteiro-Filho, 2001; Alarcon and Simões-Lopes, 2004; Kasper et al., 2004; 2008; Quintela et al. 2008). 
A noteworthy higher frequency of birds in the anthropogenic shallow lake samples is observed when compared to other studies (see Helder-José and De Andrade 1997; Pardini 1998; Colares and Waldemarin 2000; Quadros and Monteiro-Filho 2001; Kasper et al. 2008, Quintela et al. 2008) and with the other two systems sampled in the present study. In Lake A, two small islands are used as a dormitory mainly by egrets (Ardea alba, Egretta thula, E. caerulea, Bubulcus ibis), herons (Nycticorax nicticorax, Butorides striatus) and cormorants (Phalacrocorax brasilianus). The birds gather in branches of a few small trees and those individuals placed in the lowest heights could be easily predated by $L$. longicaudis during their inactivity period. Predation of the Eurasian otter Lutra lutra over water birds was observed in areas with occurrence of large bird colonies (Foottit and Butler 1977; Polechla et al. 1993; Cameron 1995, Ruiz-Olmos and Marsol 2002). Water birds are abundant in the lake studied in the present work and their high occurrence in the otter diet reveals the opportunistic habits of the species. Feathers found in scats are similar in size and color to feathers of the cormorant $P$. brasilianus and white egrets (A. alba, E. thula and B. ibis), being these species of medium and large sized water birds an important food resource for L. longicaudis in this system in particular.

Other interesting fact observed in the anthropogenic shallow lakes is the presence of carapace remains of freshwater turtles in five scats. There is only one record of testudines in $L$. longicaudis diet (Plat and Rainwater 2011) and this item has been rarely found in the diet of other river otter species such as Lontra canadensis (Greer 1955; Noordhuis 2002) and Lutra lutra (Clavero et al. 2005; Georgiev 2006). Noordhuis (2002) suggests that predation over turtles could be frequent in areas where these reptiles are abundant, but it is hard to verify once bones, skin and shells are not ingested. Clavero et al. (2005) also found the occurrence of the terrapin Mauremys leprosa in $70 \%$ of the 60 reptile individuals identified in L. lutra scats, being the remainder represented by the colubrid Natrix maura (28\%) and an unidentified lacertid (2\%). The small thickness of the fragmented scutes in the analyzed samples in the present study corresponds to juvenile structures, but predation over adult individuals can also occur, as pointed by Noordhuis (2002) for L. canadensis. It's worth noting that freshwater turtles are abundant in the two sampled lakes, and all of the five species recorded in the southern coastal plain region (Quintela et al. 2006; Quintela and Loebmann, 2009) were found in the lake systems.

Snakes were recorded in low frequencies in some studies on L. longicaudis diet (e.g. Colares and Waldemarin 2000; Quadros and Monteiro-Filho 2001, Kasper et al. 2008; Quintela et al. 2008). In the present study, the scat analysis allowed the identification of two dipsidad species (Liophis semiaureus and Helicops infrataeniatus) closely related to aquatic environments (Lema 2002; Quintela and Loebmann, 2009). In Rio Grande do Sul coastal plain, remains of Helicops infrataeniatus were identified by Colares and Waldemarin (2000) in Peixe Lagoon Park while Quintela et al. (2008) noticed the similarities between L. semiaureus scales and those found in scats from Lagoa Verde Environmental Protection Area. Aquatic snakes, therefore, represent food resources occasionally exploited by $L$. longicaudis in coastal environments of Rio Grande do Sul.

Despite the low frequencies, anuran amphibians occurred in samples of all the studied systems. Terrestrial anurans, especially species of the families Leiuperidae and Leptodactylidae, are abundant in all of the tree limnic systems (F. M. Quintela, pers. com.). The frequency of this group in analyzed scats, however, could have been underestimated due to bone fragmentation and difficulties on its identification, which was also pointed by Quadros and Monteiro-Filho (2001). It is also a fact that Weber (1990) has found a relation between amphibian availability in the environment and its presence in Lutra lutra scats, which can also occur with the neotropical otter.

Mammalian remains occurred in low frequencies in samples of all studied systems, as observed in previous investigations on species diet. As reported during preliminary analysis on this study (Quintela and Gatti 2009), predation over armadillo was observed for the first time in the otter diet. Consumption over other medium sized mammals in Rio Grande do Sul coastal plain includes the coypu Myocastor coypus (present study; Colares and Waldemarin, 2000), the cabybara Hydrochoerus hydrochaeris (Colares and Waldemarin 2000; Quintela et al. 2008), the whiteeared opossum Didelphis albiventris and the skunk Conepatus chinga, being the last identified in the food remains and may represent carcass utilization (Quintela et al., 2008). Small mammals (rodents), on the other hand, are commonly found in the otter 
diet (see Parera 1993; Helder-José and De Andrade 1997; Colares and Waldemarin 2000; Quadros and Monteiro-Filho 2001; Alarcon and Simões-Lopes 2004; Kasper et al. 2004; Quintela et al. 2008, present study), despite their low frequencies.

In the present work we verified a varied diet of $L$. longicaudis in the studied systems, with a clear predominance of fishes. We also observed a variation in the composition of minor prey items and their frequencies between the systems, which reflects the exploitation of the available food resources in each system and its surrounding terrestrial environments.

\section{ACKNOWLEDGEMENTS}

We are grateful to Chyntia Ibarra and Stefan Vilges de Oliveira for fieldwork support, Marcelo Magalhães Mércio for the English review, Cleber Palma Silva, Alexandre Miranda Garcia, Adriana Gava and Guassenir Born for lab support.

\section{REFERENCES}

Alarcon GG, Simões-Lopes PC. The neotropical otter Lontra longicaudis feeding habits in a marine coastal area, southern Brazil. IUCN Otter Spec Group Bull. 2004; 21(1): 24-30.

Albertoni EF, Prellvitz LJ, Palma-Silva C. Macroinvertebrate fauna associated with Pistia stratiotes and Nymphoides indica in subtropical lakes (south Brazil). Braz J Biol. 2007; 67: 499-507.

Albertoni EF, Palma-Silva C. Macroinvertebrados associados à macrófitas aquáticas flutuantes em canais urbanos de escoamento pluvial (Balneário Cassino, Rio Grande, RS). Neotrop Biol Conserv. 2006; 1(2): 90-100.

Artioli LGS, Vieira JP, Garcia AM, Bemvenuti MA. Distribuição, dominância e estrutura de tamanhos da assembleia de peixes da lagoa Mangueira, sul do Brasil. Iheringia, Sér Zool. 2009; 99(4): 409-418.

Barreto AP, Aranha JMR. Assembléia de peixes de um riacho da Mata Atlântica: composição e distribuição espacial (Guaraqueçaba, Paraná, Brasil). Acta Sci Biol Sci. 2005; 27(2): 153-260.

Bemvenuti MA, Moresco A. Peixes - áreas de banhados e lagoas costeiras do extremo sul do Brasil. Porto Alegre: ABRH - Associação Brasileira de Recursos Hídricos; 2005.

Blanco-Garrido F, Prenda J, Narvaez M. Eurasian otter (Lutra lutra) diet and prey selection in Mediterranean streams invaded by centrarchid fishes. Biol Invasions 2008; 10 : 641-648.

Cameron A. Apparent River Otter Predation at an Aleutian Tern Colony. Col Waterbirds 1995; 18: 91-92.
Carvalho-Junior O, Macedo-Soares LCP, Birolo AB. Annual e interannual food habits variability of a neotropical otter (Lontra longicaudis) population in Conceição Lagoon, South of Brazil. IUCN Otter Spec Group Bull. 2010; 27(1): 24-32.

Casatti L, Langeani F, Castro RMC. Peixes de riacho do Parque Estadual Morro do Diabo, bacia do Alto Rio Paraná, SP. Biota Neotrop. 2001; 1(2): 1-15.

Clavero M, Prenda J, Delibes M. Amphibian and reptile consumption by otters (Lutra lutra) in a coastal area in Southern Iberian Peninsula. Herpetol J. 2005; 15: 125-131.

Colares EP, Waldemarin HF. Feeding of the neotropical river otter (Lontra longicaudis) in a coastal region of the Rio Grande do Sul State, Southern Brazil. IUCN Otter Spec Group Bull. 2000; 17: 6-13.

Cordazzo CV, Seeliger U. Guia ilustrado da vegetação costeira no extremo Sul do Brasil. 2nd ed. Rio Grande: FURG; 1995.

Eisenberg JF, Redford KH. Mammals of the neotropics: the central neotropics (Ecuador, Peru, Bolivia, Brazil). v. 3. Chicago and London: The University of Chicago Press; 1999.

Erlinge S. Food studies on captive otters Lutra lutra L. Oikos. 1968; 19: 259-270.

Ferreira KM. Biology and ecomorphology of stream fishes from the rio Mogi-Guaçu basin, Southeastern Brazil. Neotrop Ichthyol. 2007; 5(3): 311-326.

Fischer LG; Pereira LED, Vieira JP. Peixes estuarinos e costeiros. Rio Grande: Ecoscientia; 2004.

Foottit RG, Butler RW. Predation on nesting Glaucouswinged Gulls by river otter. Can Field Nat. 1977; 91: 189190.

Georgiev DG. Diet of the otter Lutra lutra in different habitats of south-eastern Bulgaria. IUCN Otter Spec Group Bull. 2006; 23(1): 5-11.

Gori M, Carpaneto GM, Ottino P. Spatial distribution and diet of the Neotropical otter Lontra longicaudis in Ibera Lake (northern Argentina). Acta Theriol. 2003; 48(4): 495-504.

Greer KR. Yearly food habits of the river otter in the Thompson Lakes Region, north-western Montana, as indicated by scat analyses. Am Midl Nat. 1955; 54: 299313.

Haque MDN, Vijayan VS. Food habits of the Smooth Indian Otter (Lutra perspicillata) in Keoladeo National Park, Bharatpur, Rajasthan (India). Mammalia. 1995; 59: 345348.

Helder-José, De Andrade HK. Food and feeding habits of neotropical river otter Lontra longicaudis (Carnivora, Mustelidae). Mammalia. 1997; 61: 193-203.

Kasper CB, Feldens, MJ, Salvi J, Grillo HCJ. Estudo Preliminar sobre a ecologia de Lontra longicaudis no Vale do Taquari, Sul do Brasil. Rev Bras Zool. 2004; 21(1): 6572.

Kasper CB, Bastazini VAG, Feldens MJ, Salvi J, Grillo HCJ. Trophic ecology and the use of shelters and latrines by the Neotropical otter (Lontra longicaudis) in the Taquari Valley, Southern Brazil. Iheringia, Sér Zool. 2008; 98(4): 469-474.

Koch WR, Milani PR, Grosser KM. Guia ilustrado; peixes Parque Delta do Jacuí. Porto Alegre: Fundação Zoobotânica do Rio Grande do Sul; 2000. 
Krebs CJ. Ecological methodology. Menlo Park: Benjamin/Cummings; 1999.

Kruuk H, Goudswaard, PC. Effects of changes in fish populations in Lake Victoria on the food of otters (Lutra lutra Schinz and Aonyx capensis Lichtenstein). Afr J Ecol. 2008; 28: 322-329.

Kruuk H, Kanchanasaka B, O'Sullivan S, Wanghongsa S. Niche separation in three sympatric otters Lutra perspicillata, L. lutra and Aonyx cinerea in Huai Kha Khaeng, Thailand. Biol Cons. 1994; 69(1): 115-120.

Larivière S. Lutra maculicollis. Mammalian Species 2002; 712: 1-6.

Lanszki J, Pallos ZS, Nagy D, Yoxon G. Diet and fish choice of Eurasian otters (Lutra lutra L.) in fish wintering ponds in Hungary. Aquac. Int. 2007; 15: 393-402.

Lema T. de. Os Répteis do Rio Grande do Sul: atuais e fósseis - biogeografia - ofidismo. Porto Alegre: Edipucrs; 2002.

Mason C. An introduction to the otters. In: Foster-Turley P, Macdonald S, Mason C, editors. Otters: an action plan for their conservation. Gland: IUCN/SSC Otter Specialist Group; 1990. p. 4-7.

Medina-Vogel G, Gonzalez-Lagos C. Habitat use and diet of endangered southern river otter Lontra provocax in a predominantly palustrine wetland in Chile. Wildl Biol. 2008; 14(2): 211-220.

Medina-Vogel G, Delgado CR; Alvarez, RE, Bartheld J LV. Feeding ecology of the marine otter (Lutra felina) in a rocky seashore of the south of Chile. Mar Mam Sci. 2004; 20: 134-144.

Nakano-Oliveira E, Fusco R, Santos EAV, Monteiro-Filho ELA. New information about the behaviour of Lontra longicaudis (Carnivora: Mustelidae) by radio-telemetry. IUCN Otter Spec Group Bull. 2004; 21(1): 31-35.

Noordhuis R. The river otter (Lontra canadensis) in Clarcke County (Georgia, USA)-survey, food habits and environmental factors. IUCN Otter Spec Group Bull. 2002; 19(2): $75-86$

Parera A. The Neotropical river otter Lutra longicaudis in Ibera Lagoon, Argentina. IUCN Otter Spec Group Bull. 1993; 8: 13-16.

Pardini R. Feeding ecology of the neotropical river otter Lontra longicaudis in an Atlantic Forest stream, southeastern Brazil. J. Zool. 1998; 245: 385-391.

Parry GS, Burton S, Cox B, Forman DW. Diet of coastal foraging Eurasian otters (Lutra lutra L.) in Pembrokeshire south-west Wales. Eur J Wildl Res. 2011; 257: 485-494.

Passamani M, Camargo SL. Diet of the river otter Lutra longicaudis in Furnas Reservoir, south-eastern Brazil. IUCN Otter Spec Group Bull. 1995; 12: 32-34.

Pianka ER. The structure of lizard communities. Annu Rev Ecol Syst. 1973; 4: 53-74.

Plat SG, Rainwater TR. Predation by neotropical otters (Lontra longicaudis) on turtles in Belize. IUCN Otter Spec Group Bull. 2011; 28(1): 4-10.

Polechla P, Aiaginar YJ, Whiteman S. Agonistic behaviour of a mew gull (Larus canus) towards a nearctic river otter (Lontra canadensis) in Western Alaska. The River Otter J. 1993; 3: 1-2.

Quadros J, Monteiro-Filho ELA. Diet of the Neotropical Otter, Lontra longicaudis, in an Atlantic Forest Area, Santa Catarina State, Southern Brazil. Stud Neotrop Fauna Environ. 2001; 36: 15-21.
Quintela FM, Gatti A. Armadillo (Cingulata: Dasypodidae) in the diet of the neotropical otter Lontra longicaudis in Southern Brazil. IUCN Otter Spec Group Bull. 2009; 26(2): 78-81.

Quintela FM, Porciuncula RA, Colares EP. Dieta de lontra longicaudis (Olfers) (Carnivora, Mustelidae) em um arroio costeiro da região sul do Estado do Rio Grande do Sul, Brasil. Neotrop Biol Conserv. 2008; 3(3): 119-125.

Quintela FM, Loebmann D. Guia Ilustrado: Os répteis da região costeira do extremo sul do Brasil. Pelotas: USEB; 2009.

Quintela FM, Loebmann D, Gianuca NM. Répteis continentais do município de Rio Grande, Rio Grande do Sul, Brasil. Biociências. 2006; 14(2): 180-188.

Ricklefs RE. A economia da natureza. Rio de Janeiro: Guanabara Koogan; 2003.

Ruiz-Olmos J, Marsol R. New information on the predation of fish eating birds by the Eurasian Otter (Lutra lutra). IUCN Otter Spec Group Bull. 2002; 19(2): 103-106.

Rosso JJ. Peces pampeanos: guía e ecologia. Buenos Aires: L.O.L.A; 2006.

Somers MJ, Purves MG. Trophic overlap between three syntopic semi-aquatic carnivores: Cape clawless otter, spotted-necked otter and water mongoose. Afr J Ecol. 1996; 34: 158-166.

Spinola RM, Vaughan C. Dieta de la nutria neotropical (Lutra longicaudis) en la estación biológica La Selva, Costa Rica. Vida Silv Neotrop. 1995; 4: 125-132.

Spinola RM, Vaughan C. The diet of the neotropical otter (Lontra longicaudis) in Costa Rica. IUCN Otter Spec Group Bull. 1998; 19(A): 341-345.

Tagliani PRA. Ecologia da assembleia de peixes de três riachos da planície costeira do Rio Grande do Sul. Atlântica. 1994; 16: 55-68.

Uteras V, Rodrigues M, Araya I. River Yasuni national preliminary study on the diet of the neotropical otter Lutra longicaudis in the Tipunuti Park, Ecuadorian Amazonia. IUCN Otter Spec Group Bull. 1998; 19(A): 341-345.

Van der Zee D. Prey of the Cape clawless otter Aonyx capensis in the Tsitsikama Coastal National Park, South Africa. J Zool. 1981; 194: 467-483.

Vieira EF. Rio Grande: geografia física, humana e econômica. Porto Alegre: Sagra; 1983.

Vieira EF, Rangel SRS. Planície Costeira do Rio Grande do Sul: geografia física, vegetação e dinâmica sóciodemográfica. Porto Alegre: Sagra; 1988.

Votto AP, Gomes-Júnior A, Bugoni L, Pereira-Junior J. Sazonalidade da avifauna no Campus Carreiros da Fundação Universidade Federal do Rio Grande, Rio Grande do Sul, Brasil. Est Biol. 2006; 28: 45-55.

Weber JM. Seasonal exploitation of amphibians by otters Lutra lutra in north-east Scotland. J Zool. 1990; 220: 641651.

Wozencraft W.C. (2005). Order Carnivora. In: Wilson DE, Reeder DM, editors. Mammal species of the world: A taxonomic and Geographic reference. 3rd ed. Baltimore: The Johns Hopkins University Press; 2005. p. 279-348.

Received: April 19, 2011; Revised: October 27, 2011; Accepted: July 02, 2012. 